\title{
Bodily Injuries and Dative Experiencers in Old Frisian
}

\author{
Laura Bruno \\ Ghent University \\ laura.bruno@ugent.be \\ Peter Alexander Kerkhof \\ Leiden University \\ peter.alexander.kerkhof@gmail.com
}

\begin{abstract}
This article offers a descriptive account of body part constructions in Old East Frisian texts and analyzes the occurrence of dative experiencers in such clauses. This includes a comparison between Old Frisian body part grammar and its Middle Dutch counterpart, revisiting issues such as the antiquity of dative external possessors and oblique subject constructions in West Germanic. In presenting the data from a theory-neutral perspective, this investigation contributes to the study of body part grammar in Medieval Germanic in particular and to the growing body of literature on Old Frisian syntax in general.
\end{abstract}

\section{Keywords}

Old Frisian - dative experiencers - body part syntax - involvement hierarchy - Middle Low German - Middle Dutch

\section{Introduction}

Old Germanic languages have multiple grammatical constructions to recount bodily harm; by selecting different constructions, different relations between the verbal event, the body part and the possessor of the body part can be expressed (Neumann 1987, 1996; Lamiroy \& Delbecque 1998). In this article, we 
focus on one of these Germanic constructions, exemplified by Old English in (1), where the possessor of the body part (and simultaneously the experiencer of bodily harm) is marked by the dative case.
(1) 7 sloh
him of peet
heafod
and strike-3SG.PST him-DAT off DEM.ACC.sG head-ACC.sG
'[...] And he [David] struck off his [Goliath's] head' (Letter to Sigeweard, DOEC B1.8.4.4)

The purpose of the dative case in such clauses seems to have been to signal affected possessors, that is, animate referents who have an involved relationship with their possession. This noun-phrase external possessive construction is nowadays known as "dative external possessor" or "dative of inalienable possession" (Fox 1981: 324; Burridge 1996: 694; Van de Velde \& Lamiroy 2017; Rooryck \& Schoorlemmer 2017). In the more conservative scholarly traditions of Germanic and Indo-European linguistics, this use of the dative case has traditionally been classified as a sympathetic dative, or, alternatively, as a dative of belonging (the so-called Pertinenzdativ. cf. Havers 1911, Isačenko 1965, von Polenz 1969; Schmid 2006; see also Allen 2019: 1-23).

Here we may note that Old Frisian exhibits the same "he cut him the head off" construction as Old English. Just as in (1) above, the following Old Frisian example in (2) concerns a case of decapitation.
(2) sa skil
$m a$
him thet
haued
so 3SG.FUT.AUX one-Nom.sg him-DAT ART.ACC.SG head-ACC.SG
of.sla
off.strike-INF
'Then they shall strike off his head' (R2 VII, 3a) ${ }^{1}$

In both Old English and Old Frisian, this way of expressing bodily harm is competing with other constructions where the experiencer is marked with a possessive pronoun, that is, clauses of the type "he cut his head off". In the development from Old to Modern English, the former construction receded under pressure of the latter, whereas in Modern Frisian the dative construction has persisted and is still commonly used to recount injury (Van Bree 1987). However, much about the diachrony of the construction in Old Frisian is still unclear and the Old Frisian body part constructions have never been studied in detail.

\footnotetext{
1 Cf. Buma \& Ebel (1967: 149): “[...] So soll man ihm [dem Täter] den Kopf abschlagen [...]”.
} 
The aim of this article is thus to explore how Old Frisian deals with dative marking in body part constructions in order to catalogue the different construction types and investigate the semantic contexts in which these operated. For this purpose, we have drawn on the vast range of examples of bodily harm that can be found in Old East Frisian legal texts. We believe that surveying and studying these constructions in a relatively theory-neutral framework represents a valuable addition to our understanding of Old Frisian grammar in general.

This article is structured as follows: in Section 2, we first give an overview of the earlier research that has been done on Old Frisian body part constructions. In Section 3, we outline the model that constitutes our basis of description and the theoretical presuppositions that support it, which will allow us to compare the Old Frisian data with Middle Dutch. In Sections 4 and 5, we introduce the corpus which provided the Old Frisian data, comment on the philological limitations of the text types, and discuss the criteria we adopted for the data collection. In Section 6, we present and analyze the relevant Old Frisian clause types, following the description definitions and model that we defined before. In Section 7 , we give an overview of the quantitative results of our corpus study of the Old Frisian body part constructions. Finally, in Section 8, we cast a careful glance at the neighboring Germanic languages and make some remarks on the diachrony of the system. We conclude this paper with a summary of our findings on the topic of dative experiencers in Old Frisian.

\section{$2 \quad$ Earlier Research}

Old Frisian syntax has thus far been a rather understudied field; the pioneering groundwork was laid by Hanschke (1929) and later scholars such as Szadrowsky (1959; 1962), Costello (1968) and Bor (1971) followed suit. In more recent decades, additional studies were published by Van der Wal (1990), Van der Meer (1990), Lühr (2007), Bremmer (2009), De Haan \& Hoekstra (2010), Grant (2014) and Brennan (2019).

There are, however, only a few publications on Old Frisian syntax whose research focus is adjacent to ours. Bremmer (1986) deals with Old Frisian impersonal verbs of the type methinks, but limits himself to listing the different verbs and describing the environments in which they occur. Dative experiencers in sentences denoting bodily harm are not mentioned by Bremmer. Cor van Bree's 1987 study of Modern Frisian possessive constructions also included a discussion of the construction type in Old Frisian; he relates the Old Frisian dative construction of the type "he cut him the head off" to the Modern Frisian 
and dialectal Dutch ik heb de band lek constructions. Here, however, the Old Frisian data serves to contextualize the diachrony of the Modern Frisian phenomenon and is not investigated in further detail. Moreover, Van Bree only addresses a limited part of the Old Frisian corpus, first and foremost drawing his examples from the Fivelgo and Riustring manuscripts (Van Bree 1987: 100102). It therefore seems worthwhile to examine the Old Frisian data more thoroughly and thereby highlight a syntactic phenomenon that occurs remarkably frequently in the Old Frisian texts.

There is another reason to focus attention on the dative experiencer constructions. Recent discussions in the literature on dative experiencers in the Old Germanic languages justify revisiting the question of their antiquity, that is, how old these constructions were in the prehistory of Germanic. On this subject, Eythórsson and Barðdal (2005) have shown that some dative experiencers actually behave like syntactic subjects and go back to the grammar of the Proto-Germanic ancestral language (see also Barðdal \& Eythórsson 2012). Recently, Allen (2019) has conducted a thorough analysis of body part constructions in the diachrony of English, in which she corroborates the antiquity of the dative experiencer construction and provides new answers to how it competed with regular possessive constructions. It is our contention that such an analysis would also benefit Old Frisian and help define how the Frisian language continued the inherited construction types.

\section{Involvedness and Dative Experiencers}

Given the extensive literature on dative constructions and the variation in terminology therein employed, we here provide our definitions and specify which dative constructions are within the scope of our investigation. In this article, the term "dative" will be used in the tradition of Germanic historical linguistics; we define the dative as a morphologically marked case form that signals goal semantics such as receiving, experiencing and belonging. A dative case coding a recipient or a beneficiary is also known as the "dative proper" (cf. Van Belle \& Van Langendonck 1996: x). We have chosen to subsume sympathetic datives, datives of interest (ethical datives) and datives of belonging (for discussion, see Allen 2019:1-23) under the term "involved dative", because they all mark a relationship of close involvement between an animate argument and the predicate.

As discussed above, in the Old Germanic languages an involved dative can be used for expressing bodily harm. For the diachrony of English, this construction type has been catalogued by scholars such as Mitchell (1985) and Allen 
(2019) and for the diachrony of German by Krohn (1980) and Hole (2014). The construction persists in different guises in the modern Germanic languages. In Modern German, for example, it is still compulsory with affected possessors of possessed objects (Vennemann 2002: 151-152):
(3) Er schlug
ihm den
Kopf
$a b$
he-Nom strike-3sG.PST him-DAT ART.ACC.sG head-ACC.SG off 'He struck off his head'

In present-day spoken Dutch, the construction is mainly found in set clauses that have become proverbial (see also Van Bree 1996: 191):
(4) Hij hing
me de keel
uit
he-NOM hang-3SG.PST me-DAT ART throat-ACC.SG out
'He annoyed me'

A genuine Dutch counterpart to the German "he cut him the head off" example can occasionally be found in nineteenth-century prose and grammars (e.g. Ik sla u den arm stuk 'I break your arm', Cosijn 1869: 66), but it is difficult to gauge how common this construction actually was in the spoken language.

In Modern Frisian, constructions with dative body part possessors are much more common than in Modern Dutch. In his grammar of Modern Frisian, Popkema (2006: 267) considers them to be a variant of the possessive dative:
(5) $\mathrm{De}$
earen sille
dy
noch befrieze
ART.NOM.PL ear-NOM.PL 3SG.FUT.AUX you-DAT yet freeze-INF
'Your ears will yet freeze'

As mentioned before, in all of these languages, both medieval and modern, this construction can be used alongside other ways of marking the relationship between body part and body part owner, primarily by using a possessive pronoun such as his or her. This raises the question for how long involved dative constructions were used alongside regular possessive constructions and how one can define the relationship between them.

Burridge (1996) has investigated these issues in her study on Middle Dutch body part grammar. She argues that Middle Dutch clauses of the type "he cut him the head off" cannot only be interpreted as a dative of inalienability, but also as a single construction belonging to a larger semantic system that signals the degree of involvement between person and body part. According to Burridge (1996: 699), several body part constructions were available in Middle 
Dutch to encode different degrees to which the person who suffered bodily harm was involved in the verbal action; the dative of inalienability would simply be one of them. She proposes a hierarchical scale with no. 1 being the least involved and no. 5 the most involved: ${ }^{2}$

1. Mention of body part without possessing person;

2. Person expressed in a locative phrase and independent of the body part constituent;

3. Person coded as a possessive pronoun or genitive modifier of the body part constituent;

4. Person doubly coded as a dative pronoun and as a possessive pronoun modifier of the body part;

5. Person coded as dative argument independent of the body part constituent.

Burridge's system closely resembles that of Fox (1981), who argued that promoting body part owners in clauses on bodily harm from personal pronouns to dative arguments is a universal syntactic phenomenon, citing examples from languages such as French, Spanish, Igbo and Blackfoot.

Burridge continues her argument by noting that in intransitive clauses which concern bodily processes or states, also the body part could be coded with a dative case, thereby signaling that the body itself was an experiencer of the ongoing verbal event. Here the dative experiencer seems to fulfill the role of the grammatical subject and no other verbal argument is to be found in the sentence.

\section{Middle Dutch body part as oblique subject}

(6) Wan deme maghen vorkoldet is when ART.DAT.SG stomach-DAT.SG chill-PTCP be-3SG.PRS 'When the stomach has become cold' (Burridge 1996: 688)

Another example of such an argument structure is the case of Middle Dutch hem walght 'he vomits' in (7), in which the experiencer is likewise marked by the dative case. Here it is important to note that the same Middle Dutch verb walghen has the stative meaning 'to be disgusted' when it takes a nominative subject.

2 Adapted from Burridge (1996: 682-684). 
Middle Dutch experiencer as oblique subject

(7) hem walght ${ }^{3}$

him-DAT vomit-3sG.PRS

'He vomits' (Burridge 1996: 692)

According to Burridge, the dative experiencer constructions in (6) and (7) cannot be separated from sentences of the type methinks and me hungers, which also have experiencer subjects coded with oblique cases. She remarks that what the transitive clauses of the type "he cut him the head off" have in common with the intransitive ones of the type "him vomits" is that the use of the dative case marks the involitionality of the experiencer in relation to the verbal action. These peculiar constructions and their verb frames were described as early as 1907 by Pedersen but their origin remains disputed (see van der Horst 2008: 456-459; Bremmer 1986: 80; Barðdal \& Eythórsson 2009, Barðdal et al. 2018). Twenty years ago, Burridge still had to justify the analysis of Middle Dutch clauses such as "him vomits" as oblique subjects in the face of alternative explanations for the unexpected case form, e.g. the decay of the Middle Dutch case system. Now the evidence for this analysis seems solid, especially since other Germanic languages like Gothic, Old Icelandic and Old High German, where the decay of the case system is not an issue, exhibit the same case frames and constructions (cf. Van der Horst 2008; Barðdal \& Eythórsson 2012).

The Old Frisian corpus from which we have drawn our data consists of medieval legal manuscripts that were written in the fourteenth and fifteenth century, originating from the Ems and Weser areas. ${ }^{4}$ Below we present an overview of the manuscripts and the relevant texts from which we have extracted the data in alphabetical order (for a more extensive survey of the dating and redactions, see Nijdam 2008: 87, Bremmer 2009: 13-14).

- First Emsingo Codex [Er] (ca. 1400)

- General Register of Compensations

- Emsingo Book of Compensations

- Miscellaneous

3 The same way of expressing "I vomit" is attested in other Old Germanic languages, such as Old English (me wlatað), Old Saxon (mir uuillot) and Old High German (mick uuillet).

4 The data collection that is used in this article was conducted by Laura Bruno as part of her $\mathrm{PhD}$ investigation on Old Frisian dative arguments at Ghent University. 
- Second Emsingo Codex [E2] (ca. 1450)

- Chattle Oath

- Emsingo Register of Compensations

- Emsingo Book of Compensations

- Third Emsingo Codex [E3] (ca. 1450)

- Emsingo Register of Compensations

- Additions to the Land Laws and the General Register of Compensations

- Emsingo Book of Compensations

- Fivelgo Codex $[F]$ (ca. 1500)

- Seventeen Statutes

- Twenty-four Landlaws

- Magnus Statutes

- Eight Dooms

- About a thief

- General Register of Compensations

- Miscellaneous rules

- Asega Law

- Succession Law

- Fivelgo and Oldamt Statutes

- First Hunsingo Codex [H1] (ca. 1325-1350)

- Seventeen Statutes

- Hunsingo Register of Compensations (part I)

- Hunsingo Register of Compensations (part II)

- General Register of Compensations

- Second Hunsingo Codex [H2] (ca. 1325-1350)

- Seventeen Statutes

- Twenty-four Landlaws

- Hunsingo Register of Compensations

- Seven Statutes

- Exceptions to the Seventeenth Statute

- General Register of Compensations

- Hunsingo Statutes of 1252

- First Riustring Codex [R1] (ca. 1300)

- First or younger Prologue

- General Register of Compensations

- Riustring Register of Compensations

- The Elder Riustring statutes

- Second Riustring Codex [R2] (ca. 1327)

- Riustring Register of Compensations

- Miscellaneous Legal Rules 
The reason why we have selected these manuscripts is that they were all produced east of the River Lauwers and are therefore considered East Frisian (Bremmer 2009: 16). Hence, it is to be expected that the dialectal variation within these texts is rather limited, at least more so than when comparing East Frisian and West Frisian manuscripts. Furthermore, the manuscripts represent a significant part of the surviving Old Frisian text tradition (eight out of the eighteen surviving manuscripts) and contain an abundance of body part terms; these body parts are mentioned in the context of legal fees that had to be paid as a compensation for bodily injury. For every single body part a specific compensation was prescribed that was commensurate to the extent of the injury, the victim's social status and the importance of that body part to the victim's future life (Nijdam 2008: 18).

Although the Old Frisian legal stipulations concerning bodily harm are a true treasure trove for body part terminology and constructions, they also have some important limitations. The legal texts use a phraseology that does not allow for much syntactic variation; furthermore, the laws recorded in these manuscripts depend heavily on set formulae, some of which might reflect oral traditions (Bor 1982: 14; Bremmer 2014). Consequently, these legal clauses very often repeat the same structure over and over again. A large number of stipulations were even truncated to their core information, as exemplified by (8):

$$
\begin{aligned}
& \text { berd.feng annen scilling } \\
& \text { beard.grabbing one shilling } \\
& \text { '[For] pulling [someone's] beard, [one must compensate with] one shil- } \\
& \text { ling' (E3 I, 9) }
\end{aligned}
$$

However, despite their terse language and utilitarian style, the Old Frisian law texts offer a unique perspective on the different types of injury that might occur in a late medieval society. Hence, they constitute an ideal text genre to explore for language material containing information on bodily harm.

For our investigation, we have scrutinized the aforementioned texts for all the Old Frisian sentences in which body parts are mentioned. We have done this by manually reading through the text editions by Buma \& Ebel $(1963,1967,1972)$ and Hoekstra (1950) to ensure that we would not miss any possible mentions of

5 Cf. Buma \& Ebel (1967: 169): “(Für das) Ziehen am Bart (zahle man) einen Schilling”. 
body parts due to spelling variation or sentence truncation. We have collected all the instances in which body parts occur as topical elements of the information structure of a full sentence, thereby excluding the following sentence types:

- severely truncated sentences, such as (8)

- sentences in which body parts are dependent parts of noun phrases, e.g. neiles ofslech 'the striking off of a nail'

- sentences in which body part terms are used metaphorically, e.g. thet sibbesta blod 'the closest blood relative'

We have considered items to be body parts when they belong to the physical body or are intimately associated with the body such that their removal from the bodily sphere can be seen as harming the integrity of the body as a whole (see also Section 6.5). We have therefore also included the following bodily entities:

- blood

- hair

- nails

- the five senses

We have divided the collected tokens according to Burridge's classification system (1996: 699), which distinguishes five types:

1) body part without reference to body part owner

2) body part owner encoded as a location

3) body part with a possessive pronoun or genitive phrase

4) body part with the animate referent doubly coded as possessive pronoun and dative experiencer

5) body part with the animate referent coded independently from the body part constituent as a dative experiencer

We have collected these types in order to provide an overview of the ratio of body part mentions containing dative experiencers to just general body part mentions (examples are provided in Sections 6.2-4). For the collection of Types 1 and 3, we have included mentions of body parts that occur in the compensation registers or similar list-like contexts; in Types 4 and 5, we are dealing with more complete sentences. When collecting them, we decided to include "slightly truncated" sentences, where the subordinate particle "if" introducing the conditional clause is absent and the passive construction is given without the auxiliary: 
(9) her ene monne off.scheren with sin

hair-NOM.SG ART.DAT.SG man-DAT.SG off.shave-PTCP against poss haued

head-Acc.sG

'If hair is shaved from a man's head [...]' $\left(\mathrm{E}_{3} \mathrm{I}, 7\right)^{6}$

We have included them because, despite their elliptical format, the evidence for the dative experiencer construction in these sentences is recognizably present.

In some cases, we had to consider the possibility that what looks like a dative experiencer may actually be part of the verbal argument structure, a problem also mentioned by Van Bree (1987: 88-89). As a consequence, we have excluded sentences in which the dative pronoun may be dependent on the verbal argument structure, as is the case in the following example where Old Frisian den 'done' is used ditransitively with hir as indirect object and kale 'baldness' as direct object:
(10) Js
hir en
kale
ieftha en
be-3SG.PRS she-DAT ART.NOM.SG baldness-NOM.SG or ART.NOM.SG blodelsa den
bloody.wound-NOM.sg done-PTCP
'If a woman has been made baldheaded or been inflicted a bloody wound $[\ldots]^{\prime}\left(\mathrm{E}_{3} \mathrm{I}, 180\right)^{7}$

An additional point that needs to be addressed is that in later stages of Old Frisian the personal pronoun him could both be used for the accusative and the dative case, with the older accusative pronoun hine slipping into disuse (Howe 2014: 223). However, in all the manuscripts that we have studied traces of hine are found as a separate accusative case form. Furthermore, the interpretation of him as exclusively dative in these contexts is supported by analogous clauses where the injured party is represented by ene monne or enre frouwa, instances that are unambiguously marked as datives. This is our motivation for generally regarding Old Frisian him as a dative, although we recognize that occasionally accusatives may occur in these positions as well:

6 Cf. Buma \& Ebel (1967: 169): “(Wird) einem Manne das Haar bis an den Kopf abgeschoren $[\ldots]^{\prime \prime}$.

7 Cf. Buma \& Ebel (1967: 185): "Ist ihr eine Kahlheit oder eine blutende Wunde zugefügt [...]”. 
(11) Hwersa $=$ thene mon slait uppa whereso=one-NOM.SG ART.ACC.SG man-ACC.SG strike-3Sg on ene lit

ART.ACC.SG limb-ACC.SG

'If someone strikes a man on a limb [...]' $\left(\mathrm{Fx}, 33^{8}\right)^{8}$

A final remark concerns the problem of textual repetition, that is, the possibility that several manuscripts preserve the same legal stipulations or even one manuscript repeats the same legal clause in different texts. We have thus counted each mention that fits our criteria separately, even when a highly similar stipulation is found in another manuscript. Our reason for doing so is that we regard the inclusion of a legal stipulation into the manuscript not as a slavish copy from a prototype, but rather as a conscious moment in which the scribe engages both the text of his exemplar and his personal knowledge of the legal tradition. This supposition is supported by the fact that there is ample variation between various phrasings of the same legal stipulation.

(12) Anda sin nose slein thet se blede eider on Poss nose-Acc.sg hit-PTCP sub it-Nom bleed-3sg.Prs each nosterlen en scilling nostril one shilling '[If a man is] hit on his nose so that it bleeds, each nostril [...]' (E1 VII, 46) ${ }^{9}$

(13) Anda nose slaijn thet se blede aijder on nose-Acc.sg hit-PTCP suB it-NOM bleed-3sG.PRs each nostrin ane skillingar nostril one shilling '[If a man is] hit on his nose so that it bleeds, each nostril [to be compensated with] one shilling' (E2 III, 64) ${ }^{10}$

In (12) and (13) the possessive sin is present in E1 but not in E2, while the diminutive word nosterlen 'nostrils' in E1 is represented by nostrin in E2. In our opinion, such variation in phrasing justifies treating similar versions of the same legal clause as separate expressions of scribal agency and therefore separate linguistic expressions.

8 Cf. Buma \& Ebel (1972: 123): "Wenn man jemand auf ein Glied schlägt”.

9 Cf. Buma \& Ebel (1967: 69): "(Wird jemand) auf die Nase geschlagen, so daß sie blutet, (so ist die Buße für) jedes (blutende) Nasenloch ein Schilling”.

10 Cf. Buma \& Ebel (1967: 113): "(Wird jemand) auf die Nase geschlagen, so daß sie blutet, (so ist die Buße für) jedes (blutende) Nasenloch ein Schilling”. 
In the following sections, we present several Old Frisian examples that illustrate how the semantic relationship between body part and body part owner is expressed. We also elaborate on the extent to which Burridge's proposal of an involvement hierarchy for Middle Dutch can be applied to the Old Frisian body part constructions.

\subsection{Body Part as Location}

We start our presentation of the data by noting that events which involve body parts can be highlighted both from the perspective of the body part and from that of the body part owner. When considering the perspective of the body part, we follow Burridge (1996: 680) in distinguishing between, on the one hand, body parts as a core grammatical argument in the clause and, on the other, body parts as a peripheral argument in the clause, with the body part occurring in a prepositional phrase. Burridge cites the following example from the Middle Dutch Boeck van surgien, a fourteenth-century handbook on medical knowledge, in which a man's head is injured by a falling beam.
(14) Her
viel
een
balck
op siin hooft
him-DAT fall-3SG.PST ART.NOM.sG beam-NOM.SG on POss head-ACC.SG
'A beam fell on his head' (Boeck van Surgien c. 8, Burridge 1996: 681).

In (14), the body part owner is marked both as an experiencer (expressed by the dative case) and as a possessor (by use of a possessive pronoun). But what is more striking is that the body part occurs in a prepositional phrase, thereby highlighting the location of the injury rather than its effect on the body part. In the Old East Frisian texts that we have investigated, no example of this clause type was found. However, beyond the scope of our investigation, a surprisingly similar clause is present in the Old West Frisian Aysma Codex. Here we are not dealing with a falling beam, but rather with a stone falling from a church:

(15) Falt=er een steen van ener fall-3SG.PRS=there ART.NOM.SG stone-NOM.SG of ART.DAT.SG tzerka manne op syn haud church-DAT.SG ART.DAT.SG man-DAT.SG on POss head-ACC.SG 'If a stone falls from a church upon a man's head [...]' (A I, 395) $)^{11}$

11 Cf. Buma et al. (1993: 281): "Fällt ein Stein von einer Kirche auf den Kopf eines Menschen $[\ldots] "$. 
In (15), like its Middle Dutch counterpart (14), the animate referent is also marked both as an experiencer and as a body part possessor, while the body part itself occurs in the prepositional phrase op syn haud. The almost complete parallelism of the construction in the two neighboring languages makes it likely that Old Frisian and Middle Dutch expressed the same semantic nuance in the same way; in clauses such as these the location of the injury is highlighted, rather than the victim or the body part.

Sometimes the perspective shifts from body part to body part possessor within a single sentence; occasionally we find legal stipulations that contain a main clause in which the body part is marked as a location and a dependent clause in which the body part is marked as a core argument. Example (16) represents such a complicated case where body part and body part owner are expressed differently in main and dependent clauses.

\section{(16) Huasa vndad werth anda sin lungen \\ who-NOM.sG wound-PTCP 3 SG.AUX on POss lung-ACc.sG \\ thet $=s \quad$ him wr.sith ${ }^{12}$ \\ SUB=it-NOM.SG him-DAT ulcerate-3SG.PRS \\ 'If a man gets wounded in his lung so that it ulcerates $[\ldots]$ ' $(\mathrm{E} 1,171)^{13}$}

This stipulation concerns a plaintiff who is wounded in his lung, so that fluid is seeping from the wound..$^{14}$ In the main clause, the body part is marked as a peripheral argument, while the body part owner is expressed by a possessive pronoun. In the subsequent dependent clause, the lung, expressed by the co-referent enclitic pronoun $-s(e)$, is marked in the nominative, while the wounded plaintiff is coded as a dative experiencer.

\subsection{Burridge Types 1, 2 and 3}

In Section 6.1, we have considered bodily harm from the perspective of the body part. Viewed from the perspective of the body part owner, however, Burridge's hierarchy scale of involvement comes into play. According to this scale, the lowest degree of involvement between the body part owner and the injury is represented by cases in which the animate referent is left unexpressed and the body part itself is highlighted (Type 1).

\footnotetext{
12 Emended by Fokkema (1959: 29); Ms wr sich.

13 Cf. Buma \& Ebel (1967: 183): "Wenn jemand so an seiner Lunge verwundet wird, daß sie ihm vereitert [...]".

14 On wrsith, see Stiles (2007).
} 
Burridge illustrates this type with a clause from the Boeck van surgien; in example (17), the body part "cranium" is the direct object that is being acted upon by an external actor, while the owner of the "cranium" is not mentioned at all.
(17) Doen most
ic dat
ghesonde hersenbecken
then must-1SG.PST I-NOM ART.DAT.SG healthy cranium-ACC.SG drielen
drill-INF
'Then I had to drill the healthy cranium' (Burridge 1996: 682)

Old Frisian has similar constructions in which a body part is acted upon by an external force while the body part owner remains unmentioned. The Emsingo Book of Compensations contains a legal clause concerning the eventuality that someone's upper body is pierced by a sharp object (presumably a sword, a knife or a spear).

$$
\begin{array}{llll}
\text { Jeff thet } & \text { liff } & \text { wert } & \text { olsa thruch.estat } \\
\text { if } & \text { ART.NOM.SG } & \text { body.NOM.SG } & \text { 3SG.AUX } \\
\text { also through.pierced-PTCP }
\end{array}
$$
olsa to betane

also to compensate

'If the body gets pierced likewise [the wound is] to be compensated just as much' (E3 I, 45) $)^{15}$

According to Burridge's hierarchy, in (18) the body part lif'trunk, upper body' is emphasized as the core argument of the transitive verb thruchsteta 'to pierce through'.

Another example of a Type 1 construction is the following legal stipulation, in which the body part erm 'arm' is the subject of a conditional clause and the injury is expressed with the predicative adjective lom 'lame'.

(19) Jef thi erm algadur lom is

if ART.NOM.SG arm-Nom.sG altogether lame be-3SG.PRS

'If the arm is completely lame' $(\mathrm{R} 1 \mathrm{~V}, \mathrm{ga})^{16}$

\footnotetext{
15 Cf. Buma \& Ebel (1967: 170): "Wenn der Leib in dieser Weise durchbohrt wird, (so ist er) genauso zu büßen".

16 Cf. Buma \& Ebel (1963: 65): "Wenn der Arm völlig lahm ist [...]”.
} 
In examples (17) to (19), the possessor of the body part remains unmentioned. We may therefore follow Burridge in her assertion that the relationship between the body part and its owner is not in focus in such cases.

The following step in Burridge's involvement hierarchy between body part and possessor consists of constructions in which the animate argument is marked as a location (Type 2). In these cases, the body part owner is only indirectly involved and it is still the body part that has most of the focus. Burridge illustrates this type with an example concerning the cleaning of the womb in vrouwen "in women", taken from the Boec van Medicinen in Dietsche.
(20) Dat reynicht
in vrouwen
die
moder
DEM clean-3SG.PRS in woman-DAT.PL ART.ACC.SG womb-ACC.SG
'That cleans the womb in women' (Burridge 1996: 683)

In our Old Frisian corpus we have not encountered any similar constructions in which the body part owner is marked as a location rather than as a possessor or an experiencer. The ideal construction would have looked something like "if someone cuts off an ear from a man" (**hwersa ma fon ene monne en ar ofsnith), but here stylistic reasons might be to blame for the absence of this construction from our corpus; it makes sense that in law texts that have a strong "if $\mathrm{X}$ happens to Y, then Z" structure, the focus should be on either the body part or the victim. There is no specific need to use general statements that specify the location of the body part on a person, as in (20).

The next level in Burridge's hierarchy consists of constructions in which the body part owner is marked by either a possessive pronoun or a noun phrase in a genitive construction (Type 3). Since these two are the default ways of marking any kind of possession, we can limit ourselves to a single example:
(21) Sa ach
hi sine haud
to lesane mith
so must-3sG.Prs he-Nom poss head-ACC.sG to ransom with
xij merkum
12 mark-DAT.PL
'So he must ransom his head with 12 [Frisian] marks' (F III, 15) $)^{17}$

In (21), the body part is the core argument of the verb aga 'to have to, must' and the body part owner is expressed with the nominative pronoun $h i$ and the possessive pronoun sine.

\footnotetext{
17 Cf. Buma \& Ebel (1972: 37); “[...] So soll er [...] seinen Kopf vom Volke zwölf Mark lösen [...]".
} 


\subsection{Burridge Type 4: Dative Experiencer + Possessive Pronoun + Body Part}

Burridge Type 4 concerns constructions in which the body part owner is marked with a dative case and the body part by a possessive pronoun.

In example (22), a foot injury is described. In this instance, the third-person pronoun hwasa 'whoever' is in the dative and a possessive pronoun sin precedes the body part. The relation between the body part "foot" and the body part owner who experiences the bodily harm is thus doubly marked.

(22) Huamsa sin fot stedes driupt $[\ldots]$

who-DAT.SG Poss foot-NOM.sG constantly droop-3sG.PRs

'If someone's foot is constantly drooping [...]' (E3 I, 169) ${ }^{18}$

No further information is provided on how the body part owner incurred his injury. However, since our texts deal with legal disputes between two litigating parties, we may assume that whatever happened to the foot that caused it to droop did not happen volitionally to its owner.

The same construction with double coding of the injured person as both a dative experiencer and a possessor is frequently found in the corpus, as exemplified in sentences (23) to (25):

Thet him sin bli want werthe
SuB him-DAT Poss complexion-Nom.sG damage-PTCP 3 SG.AUX
'[...] So that his complexion is deteriorated' (E2 III, 35)

(24) Thet him sin ach.lid to.deile terth SUB him-DAT POss eyelid-NOM.SG downwards fold-3sG.PRS '[...] So that his eyelid is folded downwards' (E3 I, 83$)^{20}$

(25) Ther.fon send him ergerad sina fif sin there.from be-3PL.Prs him-DAT damage-PTCP POss five sense-NOM.PL 'Because of this, his five senses are damaged' ( $\mathrm{R} 1 \mathrm{~V}, 8 \mathrm{a})^{21}$

18 Cf. Buma \& Ebel (1967: 183): “Wenn jemandem der Fuß immer schlaff herabhängt [...]”.

19 Cf. Buma \& Ebel (1967: 111): “[...] So daß sich seine Gesichtsfarbe verändert [...]”.

20 Cf. Buma \& Ebel (1967: 175): “[...] daß ihm das Augenlid nach unten umgeschlagen ist [...]".

21 Cf. Buma \& Ebel (1963: 63): “[...] Infolgedessen sind einem die fünf Sinne verschlechtert”. 
The examples above recount bodily harm from the victim's perspective, in which the involvement between body part and body part owner is high, the latter being promoted from a possessive pronoun to both possessor and dative experiencer. It seems clear to us that both Old Frisian and Middle Dutch possessed this dative experiencer construction and it seems plausible that both languages used it for expressing the same semantics.

Here we should note that some scholars (e.g. Mustanoja 196o; Vennemann 2002) consider clauses of the double coding type ("he cut him his head off") to be a stylistic variant of the single coding type ("he cut him the head off"), which will be discussed in Section 6.4. From a structural perspective this makes sense, since both the possessive pronoun in "he cut him his head off" and the demonstrative in "he cut him the head off" express the same degree of definiteness. Vennemann (2002: 153) therefore argues that grammatically the sentence types are identical. In our opinion, however, the two construction types are rightfully kept apart in Burridge's framework; if the use of a possessive pronoun and the dative experiencer are placed on different levels of the involvement hierarchy, the combination of the two types should therefore logically represent an intermediary stage.

\subsection{Burridge Type 5: Dative Experiencer + Definite Article + Body Part}

We then move on to the last type in Burridge's hierarchy, namely a clause where the body part owner is only coded as a dative experiencer and the body part is preceded by a definite article. By leaving out the possessive pronoun and having the person occur separately from the body part, the animate argument is singled out as the most topical element of the clause.

Example (26) consists of a subordinate clause, concerning a man who is hit on his head so hard that blood comes out of "the seven holes". ${ }^{22}$ In this example, the body part in question is the blood. As mentioned in Section 5 , it is our contention that blood, together with all other bodily fluids, conceptually is classified as a part of the human body, and therefore semantically behaves like any other body part (cf. Lehmann 2018: 8).

22 The number seven refers to the eyes, nostrils, ears and mouth and probably also had a symbolic value (Bremmer 2014: 12). 
(26) Thet him thet bloed et=tha sogen
sUB him-DAT ART.NOM.SG blood-NOM.SG at=ART.DAT.PL seven
holem wt.runnen si
hole-DAT.PL out.run-PTCP be-3SG.SBJv
'[...] So that blood poured out of the seven orifices' (E3 I, 38 $)^{23}$

The structure of (26) fits Burridge's classification (1996: 684) as a body part construction in which the person's involvement is primary, while the body part is no longer an independent entity, but rather an aspect of the person. This accounts for the presence of the definite article thet instead of a possessive pronoun sin preceding the body part. The body part, in this case blood, is marked with the nominative case and the body part owner is expressed by the dative experiencer him.

Manuscripts E1 to 3 provide various other instances of construction Type 5 . The example in (27) contains the same configuration, where "blood" as a body part is combined with the experiencer in the dative case.

(27) Hvasa otherem oppa then buc hlapth thet him thet bloet eta munde vp hlapth tua pond to bote

him thet bloet et=tha munde

him-DAT ART.NOM.SG blood-NOM.SG at=ART.DAT.SG mouth-DAT.SG vp.hlapth

up.leap-3SG.PRS

'[If someone jumps onto someone else's belly so that] blood gushes forth from his mouth [he has to compensate with two pounds]' $\left(\mathrm{E}_{3} \mathrm{I}, 208\right)^{24}$

A similar example is (28), but here a damaged bodily function (Old Frisian huardlar "rotations", $25 \mathrm{cf}$. Bremmer 2014: 12) is the object of the clause.

23 Cf. Buma \& Ebel (1967: 171): “[...] So daß ihm das Blut aus den sieben Höhlen (des Kopfes) herausgeronnen ist [...]".

24 Cf. Buma \& Ebel (1967: 189): "[Wenn jemand einen anderen in den Bauch tritt, so daß] ihm das Blut aus dem Munde herausrinnt, [(so zahle er) zwei Pfund als Buße]".

25 This specific stipulation refers to an injury in the spine, which would consequently hamper certain body movements, here called "rotations"; these movements are described later in the original text. 


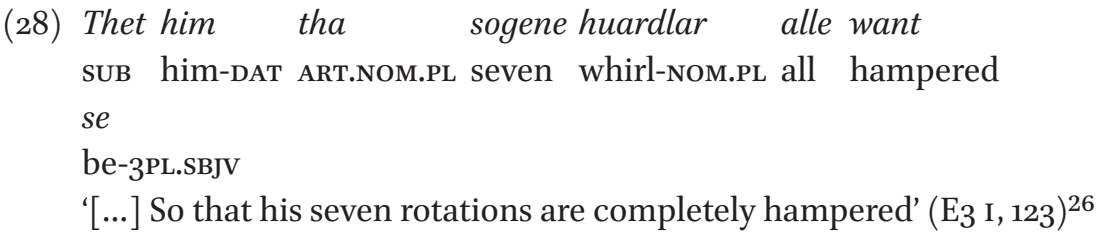

Examples (27) and (28) can also be analyzed as Burridge Type 5 constructions: the presence of a dative experiencer defines the involvement of the body part owner as a passive undergoer. As stated in Section 5 , in this construction type, the involvement of the body part owner is most marked (cf. Burridge 1996: 684-686).

\subsection{Dative Experiencers and the Extended Body}

So far we have exclusively examined clauses with body parts and dative experiencers; we may however note that items which can be considered an extension of the body behave in a similar way. Burridge (1996: 685) has shown that in Middle Dutch anything that is closely associated with the body uses the involved possessor construction; this includes speech, mind, hair, nails, bodily fluids, sores, wounds, sickness, fever, but also clothes. Isačenko (1965) and von Polenz (1969) make the same observation for Modern German, extending the range of the construction to include not only body parts and clothes but also kinship terms and other items that closely affect the animate argument (Krohn 1980: 51; Schmid 2003: 955).

In the case of Old Frisian, we may point to example (29) that fits this category and concerns violently removing someone's mantel or fur coat:

(29) Hvasa otherem off.split hrock jeftha
who-NOM.SG other-DAT.SG off.split-3SG.PRs mantel-ACC.sG or
tziust
fur.coat-ACC.SG
'If a man rips off another man's mantel or fur coat [...]' (E3 II, 16)

Just as in the clauses with bodily injury, in (29) the afflicted party is marked by a dative experiencer and no possessive pronoun is used. Here the experiencer

26 Cf. Buma \& Ebel (1967: 179): “[...] So daß ihm die sieben Wirbel alle (an ihrer Tätigkeit) behindert sind $[\ldots] "$.

27 Cf. Buma \& Ebel (1967: 201): "Wer einem anderen den Rock oder den Pelz herunterreißt, (verwirkt) sechs Schillinge" 
is in focus and the clothing items feature as "extended body part", unmarked by a determiner.

Example (30) concerns the act of tearing someone's undergarments or breaking his belt, the latter presumably to the effect that it would have been hard for him to keep his pants up. By damaging the clothing that serves to guard a person's honor, his bodily integrity would be infringed on in much the same way as actually hurting him physically.

\section{(30) Thet him sin sondema terant se jefta \\ suB him-DAT poss undergarment-NOM.sG torn be-3sG.SBJv or \\ sin brockgherdel tebretsin \\ poss belt-NOM.sG broken.asunder \\ 'So that his undergarment is torn apart or his belt is broken asunder' (E2 III, 176$)^{28}$}

Here, the injured party is again marked with a dative and a possessive pronoun precedes the damaged undergarment and belt. These body-part-like entities constitute the core argument of the clause and are marked by the accusative case as the direct object of a passive construction. Note that the clause structure runs completely parallel to the body part constructions described above. In our opinion, these examples fit the hypothesis that the Old Frisian concept of the body exceeded the physical body strictu sensu and also included clothing and bodily accessories that were deemed integral to one's person (cf. Wierzbicka 1979: 336, Fox 1981: 326, Lehmann 2018: 31).

\section{$7 \quad$ Old Frisian Body Part Constructions: Statistics}

In this section we present a quantitative analysis of our research on Old Frisian body part constructions that we have extracted from $\mathrm{E}_{1}, \mathrm{E} 2, \mathrm{E}_{3}, \mathrm{R} 1, \mathrm{R} 2, \mathrm{H} 1, \mathrm{H} 2$, and F (see Table 1). In total, we have collected 888 tokens of body part mentions from the texts. Of these 888 tokens, a considerable amount came from $\mathrm{F}$, that is, 318 . This high proportion is explained by the fact that $\mathrm{F}$ contains 302 Burridge Type 1 sentences (mentions of a body part without a possessor), most of them from the General Register of Compensations. The same observation applies to $\mathrm{R} 1, \mathrm{R} 2, \mathrm{H} 1$ and $\mathrm{H}_{2}$, whose compensation registers also contain relatively many Type 1 constructions, although not to the same extent as those in F.

28 Cf. Buma \& Ebel (1967: 127): “[...] daß jemandem seine Leibbinde zerrissen oder sein Hosengürtel zerbrochen wird". 
TABLE 1 Frequency of Burridge's Types in the Old Frisian corpus

\begin{tabular}{lccccccccr}
\hline & E1 & E2 & E3 & R1 & R2 & H1 & H2 & F & results \\
\hline Type 1 & 33 & 27 & 41 & 25 & 17 & 56 & 61 & 302 & 562 \\
Type 3 & 13 & 22 & 18 & 2 & 2 & 29 & 29 & 6 & 121 \\
Type 4 & 24 & 26 & 31 & 8 & 2 & 10 & 11 & 1 & 113 \\
Type 5 & 3 & 13 & 21 & 2 & 3 & 19 & 22 & 9 & 92 \\
tokens & 73 & 88 & 111 & 37 & 24 & 114 & 123 & 318 & 888 \\
dative exp & $36,99 \%$ & $44,32 \%$ & $46,85 \%$ & $27,03 \%$ & $20,83 \%$ & $25,44 \%$ & $26,83 \%$ & $3,14 \%$ & \\
\hline
\end{tabular}

If we include the instances from $\mathrm{F}$ and count the clauses that contain an involved dative construction (Types 4 and 5), we arrive at a number of 205 involved dative constructions, representing 23,09 percent of all body part mentions; this means that almost a quarter of the body part mentions use an involved dative construction. For E1 to $\mathrm{E}_{3}$, the percentage of involved dative constructions is between 37 and 47 percent, while $\mathrm{H}_{1}, \mathrm{H}_{2}$, R1 and $\mathrm{R} 2$ hit slightly lower numbers (between 21 and 27 percent). Only F, with its disproportionately large amount of Type 1 tokens, shows completely different ratios between the construction types (only three percent involved dative constructions), thereby seriously distorting the percentage of dative experiencer against non-dative experiencer types. When we exclude $\mathrm{F}$ from the statistics, we arrive at 570 body part mentions, of which 195 are dative experiencers (34,2 percent). Figures 1 and 2 contain two circle diagrams showing the different ratios of dative experiencers with and without $\mathrm{F}$.

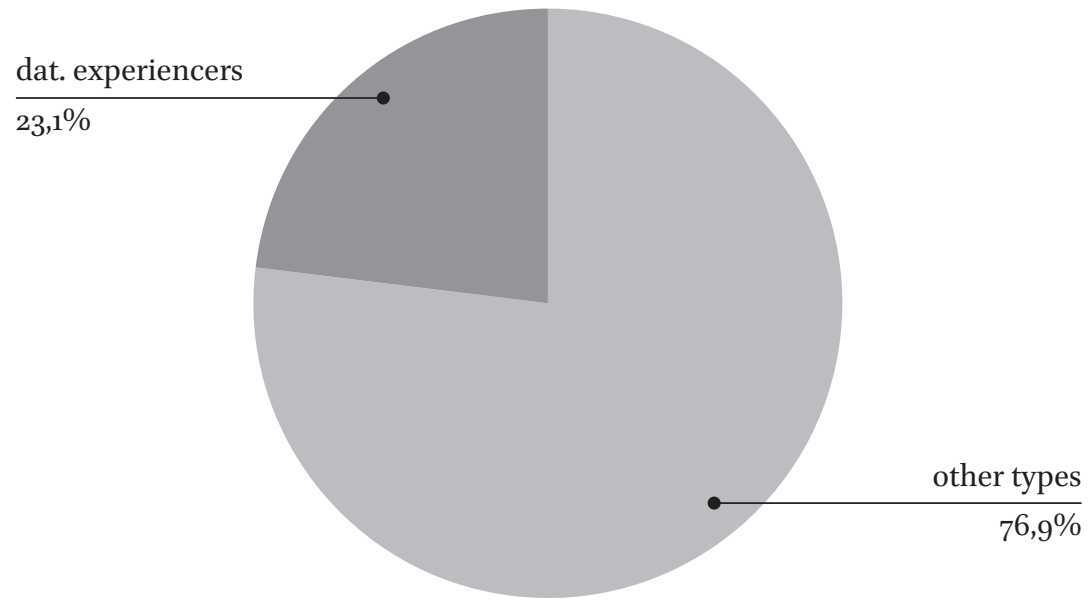

FIGURE 1 Percentage of dative experiencer constructions including F 


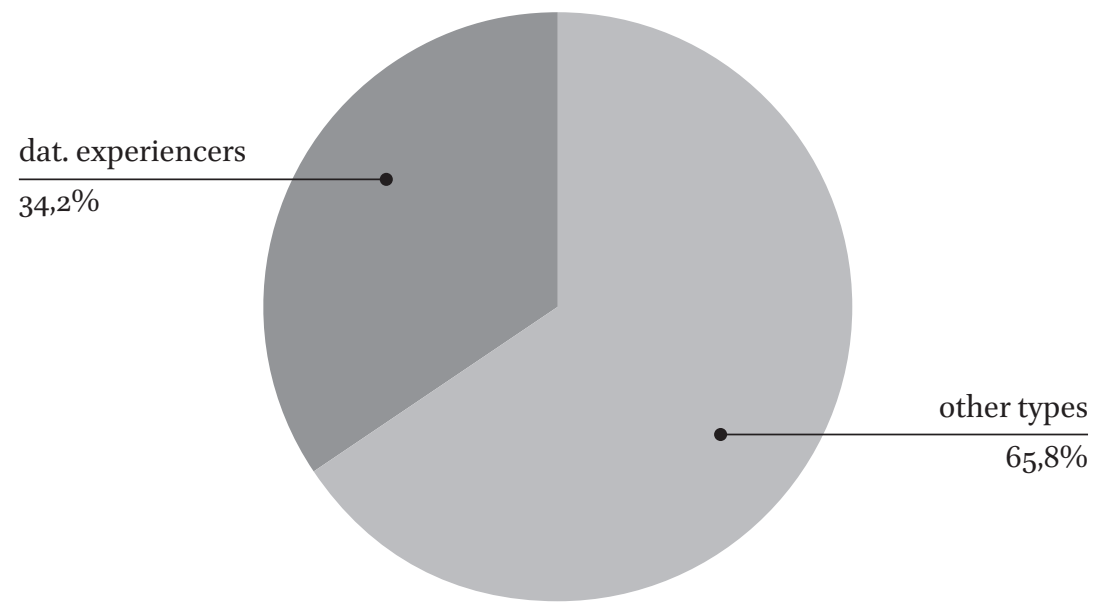

FIGURE 2 Percentage of dative experiencer constructions excluding F

We are still left with the question why the compensation registers (especially those in F) contain so many Type 1 clauses. In this regard, we should note that the compensation registers are functional lists whose main purpose was to establish the amount of compensation required for all kinds of physical injuries; it is then not surprising that body part owners are rarely mentioned in these registers. Only when there is more context and the victim is more in focus, do the dative experiencers come into play.

Some major conclusions that can be drawn from the statistics concern the relationship between Type 3 clauses, on the one hand, and Types 4 and 5 (the dative experiencers), on the other. In our opinion it is significant that, even if we include $F$, the involved dative constructions of Types 4 and 5 by far outnumber those that have the body part owner coded as a possessive pronoun or a genitival phrase. Of the 326 tokens in which the body part owner is mentioned - Types 3, 4 and 5 taken together - 205 represent involved dative constructions (Types 4 and 5), yielding a percentage of 62,88\% (see Figure 3). We may therefore conclude that the Old Frisian lawyers who drafted the legal texts favored an involved dative construction over a possessive pronoun or possessive genitive for expressing the relation between the body part owner and the injured body part.

Finally, we may wonder whether the ratio between Type 4 and Type 5 is significant in terms of Old Frisian syntax. In this regard, it is noteworthy that in almost all manuscripts, $\mathrm{R} 2$ and $\mathrm{F}$ excluded, the construction of Type 4 with both dative experiencer and possessive pronoun outnumbers the dative experiencer of Type 5. Although it is premature to draw definitive conclusions from the present corpus, one could argue that the liberal use of the redundant 


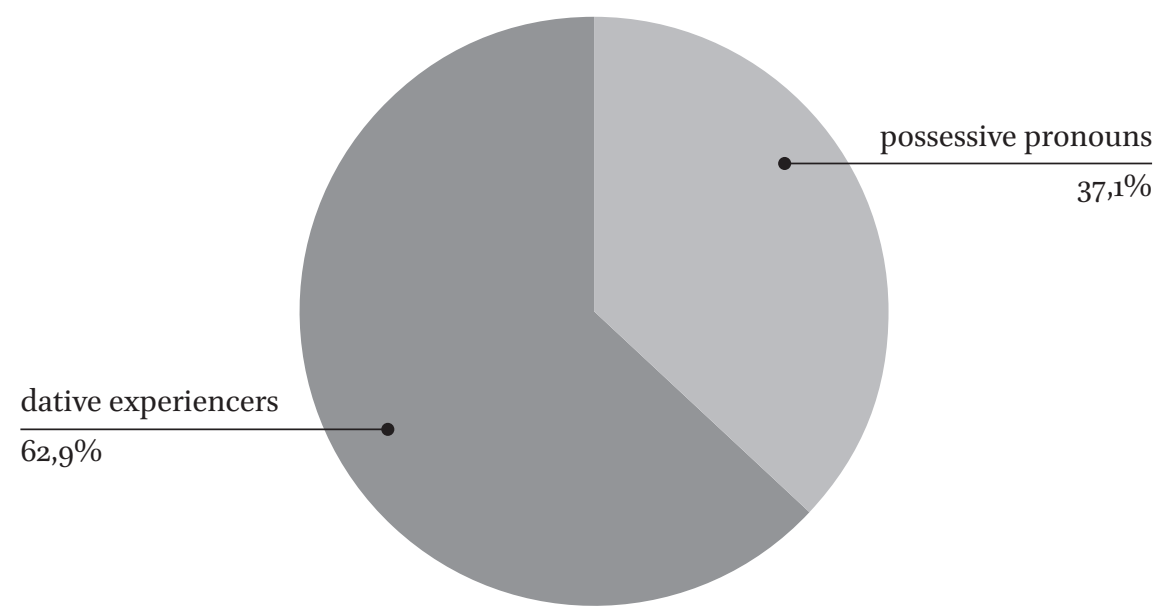

FIGURE 3 Percentages of body part owners expressed with a dative experiencer construction and with a possessive pronoun.

construction represents an intermediary stage in the gradual decline of the involved dative in these kinds of contexts. A similar conclusion has been reached for Middle Dutch and Middle English (Ahlgren 1946, Van Bree 1987: 97, Vennemann 2002: 150). Very recently, however, Allen (2019) showed that in the case of Old English, the use of the redundant construction was not connected to the decline of the dative external possessor. It therefore seems prudent to revisit the correlation between the Old Frisian construction types in a later study.

\section{Common Inheritance}

In the preceding paragraphs, we highlighted the similarities between Old Frisian and Middle Dutch in constructions concerning bodily harm, which support the concept of an involvement hierarchy underlying the application of different construction types. This raises the question of how old the proposed involvement scale in Germanic body part constructions is. In the introduction above we have shown that involved dative constructions in these contexts are also known from Old English, which would argue for their considerable antiquity. Old High German, too, features an early prototype of this semantic system, more precisely Burridge Type 4, in the famous Merseburg Charm (Braune 1928: 88$): 29$

29 Some scholars claim that the dative argument in this clause is dependent on the verb birenken (Ebert 1978: 12), but it should be pointed out that this cannot be verified because of the limited occurrences of the verb in Old High German. 
(31) Du uuart demo balderes volon sin then 3sg.AuX ART.DAT.Sg Balder-GEN.Sg foal-DAT.SG POss vuoz birenkit

foot-NOM.SG sprain-PTCP

'Then the foot of Baldr's foal was sprained'

However, it has been noted that involved dative constructions are rare in Old High German and the frequency of the construction type only starts to increase in Middle High German texts (cf. Fleischer \& Schallert 2011: 97-98).

When we look at Middle Low German, a linguistic variety that neighbors Old Frisian, we find that the similarities to the Middle Dutch and Old Frisian system are more pronounced. The following examples come from Das Arzneibuch des Johan van Segen (Alstermark 1977), a Low German medical treatise that contains an abundance of body part terms. Note how (32) below runs parallel to the Old Frisian thet him thet bloed eta sogen holem wt runnen si (see 26 above); the experiencer is in the dative case and the bodily fluid, preceded by the definite article, in the nominative, exactly as in (26):

Dat em dat blut to munde vnd to
sub him-DAT ART.NOM.SG blood-NOM.SG to mouth-DAT.SG and to
nese vit.geit
nose-DAT.SG out.go-3SG.PRS
'[...] So that blood comes out of his mouth and nose' (Alstermark 1977:
$56,39)$

Other examples from the Middle Low German medical literature are (33) where antlat 'face' is affected by the intransitive verb swellen 'to swell' and (34) where bein 'leg' is affected by the compound predicate sin enttwe 'to be in two':

(33) Wem dat antlat swellet who-DAT.SG ART.NOM.SG face-NOM.sg swell-3SG.PRS 'If someone has a swollen face [...]' (Alstermark 1997: 110, c. 376)

(34) Wem bein enttwe ist who-DAT.SG ART.NOM.SG leg-NOM.sG in.two be-3SG.PRS 'If someone's leg is broken in two [...]' (Alstermark 1977: 81, c. 176)

As shown by (33) and (34), Middle Low German shares the same semantic system as Middle Dutch and Old Frisian for signalling involvement in body part clauses. 
That at least some of Burridge's construction types already existed in the Early Middle Ages is clear from the Old English and Old High German examples. However, it is only in the Middle Germanic period that we find a wider part of the involvement scale represented in the data. This may partly be due to the limitations in size and genre of the Old English and Old High German texts, but it is also conceivable that the full scope of the system did not yet exist in the Early Medieval period.

A second diachronic point is the issue of the oblique subject constructions. As mentioned in Section 3, Burridge identified several cases in Middle Dutch where the body part functions as an oblique subject; in these clauses, the body part, marked by a dative case, is the main argument of the predicate (see Burridge 1993; 1996). The selection of data that we presented for Middle Low German, however, predominantly shows a construction type where the body part is in the nominative case and occurs alongside an experiencer in the dative case. Nonetheless, there are also some examples from Middle Low German where the nominative is completely absent:

(35) Wem jn dem hals we ist

who-DAT.SG in ART.DAT.SG neck-DAT.SG woe be-3SG.PRS

'If anyone has pain in their neck [...]' (Alstermark 1977: 108, 361)

(36) Wem we ist jn dem magen

who-Dat.SG woe be-3sG.PRS in ART.DAT.SG stomach-DAT.SG

'If anyone has a stomachache [...]' (Alstermark 1977: 119, 439)

The examples in (35) and (36) represent the "me is woe" construction (cf. Latin vae mihi, see Barðdal et al. 2013), in which the compound predicate "to be woe" has no nominative subject but takes instead a dative experiencer as its main argument. In these clauses, the body part occurs in a prepositional phrase highlighting the location of the bodily harm. According to Burridge's analysis, the dative experiencer is here in focus and the body part is deemphasized as a peripheral argument, thereby stressing that it is being acted upon (Burridge 1996: 681).

In Old Norse and Old High German, we find the same kind of oblique subject construction where the body part is relegated to a prepositional phrase:

\section{Old Norse}

(37) Svo stíngr mik i hjarta $=$ ठ

so sting-3SG.PRS me-ACC in heart $=$ ART

'My heart aches much' (Möllers 1858: 810, Biskupa sögur, vol. 1) 


\section{Old High German \\ Hiar suidit manne ana uuank \\ here burn-3SG.PRS man-DAT.SG on cheek-DAT.SG \\ 'Here the man's cheek burns' (Müllenhoff 1878: 85, Otfrid v. 23, 149)}

The question here is whether such constructions were also possible in Old Frisian, that is, whether Old Frisian exhibits body part constructions in which the verb, denoting bodily harm, took a dative experiencer as its sole argument. Bremmer (1986) has noted that in Old Frisian we find relatively few verbs with oblique subjects (which he calls "pseudo-subjects"); nevertheless, he was able to identify a dozen of such verbs that have a non-canonical case frame. These include psych-verbs such as thinza/thinka 'to seem', hagia 'to please', nogia 'to satisfy' and angia 'to fear', as well as verbs of "happenstance" such as onfalla and skia, both meaning 'to happen' (Bremmer 1986: 80). Verbs that denote bodily harm are absent from his survey, which leads us to consider two scenarios: 1) Old Frisian did at one point possess verbs that denoted bodily harm with dative or accusative arguments, but lost them before the start of the Old Frisian manuscript tradition, or 2) Old Frisian possessed verbs that denoted bodily harm with dative or accusative arguments but they do not show up in the transmitted texts. This scenario was also suggested by Bremmer (1986: 75) and we are inclined to agree for the following reason: we may note that bodily harm in the Old Frisian law texts is mainly expressed by transitive verbs which were less likely to have such case frames anyway (Burridge 1996: 69o, Barðdal \& Eythórsson 2009). In our opinion, the lack of oblique subjects in Old Frisian examples of body parts is therefore mainly a consequence of the text genre and its pragmatic requirements (cf. Bremmer 1986).

The aim of this article has been to catalogue Old Frisian body part constructions and investigate whether the Old Frisian dative experiencer constructions are compatible with the person - body part involvement hierarchy that Burridge (1996) proposed for Middle Dutch. We have done this by drawing from Old East Frisian legal texts, in particular those concerning compensations for bodily injuries. The data presented in this article were collected from a sizeable part of the Old Frisian corpus, covering the E, R, H and F manuscripts.

We have shown that Old Frisian exhibits the same kind of transitive body part constructions as Middle Dutch and would therefore allow interpretation according to the same involvement hierarchy. We agree with Burridge that the 
use of dative experiencers in transitive body part constructions is a way to highlight non-volitionality and non-agentivity of the experiencer with regard to the verbal event and therefore is closely connected to the oblique subject constructions known from other Old Germanic languages.

While assessing the quantitative part of our research, we have found that the involved dative construction in which the body part owner is marked as a dative experiencer occurs far more often than possessive constructions in which the animate referent is marked by a personal pronoun or genitival phrase. Following Burridge's hierarchy, this discrepancy can be accounted for by the greater involvement between body part and possessor that stems from promoting the possessor to a "dative experiencer". It could be argued that highlighting the relation between body part and body part owner in this way was stylistically expedient in texts that relate bodily harm which is perpetrated by one party upon the other.

Earlier studies have established that the prototype for the involved dative construction in body part clauses was already present in Old English and Old High German. This suggests that the origin of this construction can be projected back into the Proto-West-Germanic pre-stage. We suspect, however, that Burridge's involvement hierarchy is significantly younger. This follows from the observation that in the aforementioned Old Germanic languages, the use of involved dative constructions seems rather limited.

Furthermore, whereas Middle Dutch and Middle Low German provide evidence for oblique subject constructions in clauses concerning bodily harm, we have been unable to find any such evidence for Old Frisian. This is most likely due to the limited scope of our texts, since oblique subjects are most often found in sentences of low transitivity, that is, bodily harm coming from the body itself through illness or malady. However, the majority of our Old Frisian texts are law texts describing transitive verbal events where bodily injury is externally caused to another person's body. It is therefore to be expected that relatively few examples of oblique subject constructions are present in these textual environments.

Additional research is needed to explore the subject of Old Frisian body part constructions further. Adding the remaining Old Frisian manuscripts to the data set would be desirable in order to establish whether they corroborate the findings presented in this article. Another line of investigation would be to include more Old and Middle Germanic languages in this analysis; it would be especially instructive to see to what degree Middle High German exhibits the same construction types as Middle Dutch, Old Frisian and Middle Low German. Further research is also needed on uncovering how Middle English compares to Old Frisian in these kinds of contexts. Involving more languages 
in this investigation might strengthen the case of the dative experiencer construction being inherited from an earlier stage and shed more light on how in the Middle Germanic period the more extensive involvement hierarchy came into being.

\section{Acknowledgements}

For comments and discussions, we would like to thank Cynthia Allen, Carlee Arnett, Jóhanna Barðdal, Anne Breitbarth, Rolf Bremmer and Michiel de Vaan. We also extend our gratitude to the audience at the Oudgermanistendag 2018, the ICCG1O conference 2018 in Paris and the SLE conference 2018 in Tallinn, to whom we presented earlier versions of this paper. This research was supported by Ghent University's Special Research Fund (BOF) and a European Research Council (ERC) grant to Jóhanna Barðdal (EVALISA, grant nr. 313461).

\section{References}

Ahlgren, A., 1956. On the Use of the Definite Article with 'Nouns of Possession' in English. Uppsala: Appelbergs Boktryckeriaktiebolag.

Allen, C. L., 2019. Dative External Possessors in Early English (Oxford Studies in Diachronic \& Historical Linguistics) Oxford.

Alstermark, H., 1977. Das Arzneibuch des Johan van Segen. Stockholm: Almqvist \& Wiksell International.

Barðdal, J., and T. Eythórsson, 20og. "The Origin of the Oblique Subject Construction: An Indo-European Comparison", in: Grammatical Change in Indo-European Languages, eds. V. Bubenik, J. Hewson, and S. Rose. Amsterdam: John Benjamins, 179-193.

Barðdal, J., and T. Eythórsson, 2012. "Hungering and Lusting for Women and Fleshly Delicacies: Reconstructing Grammatical Relations for Proto-Germanic", in: Transactions of the Philological Society 110 (3), 363-393.

Barðdal, J., V. Bjarnadóttir, S. Danesi, T. K. Dewey, T. Eythórsson, C. Fedriani, and T. Smitherman, 2013. "The Story of 'Woe", in: Journal of Indo-european Studies 41(3-4), 321-377.

Barðdal, J., N. Pat-El, and S. M. Carey, 2018. Non-Canonically Case-Marked Subjects: The Reykjavík-Eyjafjallajökull Papers. Amsterdam/Philadelphia: Benjamins.

Van Belle, W., and W. van Langendonck, 1996. The Dative. Volume I: Descriptive Studies. Amsterdam/Philadelphia: Benjamins. 
Bor, A., 1971. Wordgroups in the Language of the 'Skeltana Riucht'. A Syntactic Analysis with Occasional Lexicographical Observations; Followed by an Inquiry into Its Punctuation and the Possibility of the Influence of Spoken Language, Dissertation (Wageningen: Veenman \& Zonen, 1971).

Bor, A., 1982. "An aspect of word order in Frisian", in: Us Wurk 31, 13-28.

Braune, Wilhelm, 1928. Althochdeutsches Lesebuch. Halle: Max Niemeyer Verlag.

Van Bree, C., 1987. "Hebben- en Datiefconstructies in het Friese en (Nederlandse) Taalgebied", in Ta de Fryske Syntaksis, eds. S. Dyk and J. Hoekstra (Leeuwaarden: Fryske Akademy, 81-103.

Van Bree, C., 1996. Historische Taalkunde. Leuven/Amersfoort: Acco.

Bremmer, R. H. Jr., 1986. “The So-Called "Impersonal-Verb”-Construction in Old Frisian”, in: NOWELE 8, 71-95.

Bremmer, R. H. Jr., 2009. An Introduction to Old Frisian. History, grammar, reader, glossary. Amsterdam/Philadelphia: Benjamins.

Bremmer, R. H. Jr., "The Orality of Old Frisian Law Texts", in Directions for Old Frisian Philology, eds. R.H. Bremmer Jr., S. Laker and O. Vries (ABäG 73, 2014), 1-48.

Brennan, R. K., 2019. "Conditional Sentences in the Old East Frisian Brokmonna Bref", in: NOWELE 72 (1), 11-41.

Buma, W. J., and W. Ebel, 1963. Das Rüstringer Recht. Göttingen/Berlin/Frankfurt: Musterschmidt-Verlag.

Buma, W. J., and W. Ebel, 1967. Das Emsiger Recht. Göttingen: Vandenhoeck \& Ruprecht. Buma, W.J., and W. Ebel, 1972. Das Fivelgoer Recht. Göttingen:Vandenhoeck \& Ruprecht. Buma, W J., P. Gerbenzon and M. Tragter-Schubert, 1993. Codex Aysma. Assen/ Maastricht: Van Gorcum.

Burridge, K., 1993. Syntactic Change in Germanic. Amsterdam/Philadelphia: Benjamins. Burridge, K., 1996. "Degenerate Cases of Body Parts in Middle Dutch", in: The grammar of inalienability. A typological perspective on body part terms and the part-whole relation, eds. H. Chappel and W. McGregor Berlin/New York: De Gruyter, 679-710

Cosijn, P. J., 1869. Nederlandsche Spraakkunst: Syntaxis. Haarlem: Erven F. Bohn.

Costello, J. R., 1968. Eine syntaktische Studie des Altfriesischen, Dissertation. New York: New York University.

De Haan, G. J., and J. Hoekstra 2010. Studies in West Frisian Grammar: Selected Papers by Germen J. de Haan. Amsterdam: Benjamins.

DOEC = Dictionary of Old English Web Corpus, compiled by Antonette diPaolo Healey with John Price Wilkin and Xin Xiang. (Toronto: Dictionary of Old English Project 2009). UR L: https://tapor.library.utoronto.ca/doecorpus/

Ebert, R. P., 1978. Historische Syntax des Deutschen. Stuttgart: J. B. Metzler.

Eythórsson, T., and J. Barðdal, 2005. "Oblique subjects: A common Germanic inheritance", in: Language 81 (4), 824-881. 
Fleischer, J., and O. Schallert, 2011. Historische Syntax des Deutschen: Eine Einführung. Tübingen: Narr Francke Attempto.

Fokkema, K., 1959. De derde Emsiger Codex. The Hague: Martinus Nijhoff.

Fox, B., 1981. "Body Part Syntax: Towards a Universal Characterization", in: Studies in Language 5 (3), 323-342.

Grant, C. J., 2014. "Two Aspects of Nominal Style in the Seventeen Statutes and Twentyfour Landlaws", in: Directions for Old Frisian philology, eds. R. H. Bremmer Jr., S. Laker and O. Vries (ABäG 73), 119-144.

Hanschke, H., 1929. Der Gebrauch der Kasus im Altostfriesischen (Nominativ und Akkusativ). Dissertation Kiel: Universität Kiel.

Havers, W., 1911. Untersuchungen zur Kasussyntax der indogermanischen Sprachen. Strassburg: Trübner.

Hoekstra, J., 195o. De eerste en de tweede Hunsinger Codex. The Hague: Martinus Nijhoff. Hole, D., 2014. Dativ, Bindung und Diathese. Berlin/Boston: De Gruyter.

Van der Horst, J. M., 2008. Geschiedenis van de Nederlandse Syntaxis. Deel 1. Leuven: Leuven University Press.

Howe, S., 2014. "Old Frisian personal pronouns: morphology and change”, in: Directions for Old Frisian philology, eds. R. H. Bremmer Jr., S. Laker and O. Vries (ABäG 73), 201-242.

Isačenko, A. V., 1965. "Das syntaktische Verhältnis der Beziehungen von Körperteilen im Deutschen", in: Studia Grammatica 5, 7-27.

Krohn, D., 1980. Dativ und Pertinenzrelation. Syntaktisch-semantische Studien unter besonderer Berücksichtigung von Lexemen mit dem Merkmal (Kleidungsstück). Göteborg: Acta Universitatis Gothoburgensis.

Lamiroy, B., and N. Delbecque, 1998. "The possessive dative in Romance and Germanic languages", in: The Dative: Theoretical and Contrastive Studies, eds. W. van Belle \& W. van Langendonck. Amsterdam: John Benjamins, 29-74.

Lühr, R., 2007. "Bedingungssätze in altfriesischen Rechtstexten", in: Advances in Old Frisian Philology, eds. R. H. Bremmer Jr., S. Laker and O. Vries (ABäG 64), 213-238.

Van der Meer, G., 1990. "On the position of the Old Frisian verbs and pronouns", in: Aspects of Old Frisian philology, eds. R. H. Bremmer Jr., G. van der Meer and O. Vries (AB̈̈G 31-32), 311-335.

Mitchell, B., 1985. Old English Syntax. Oxford: Oxford University Press.

Möllers, S. L., 1858. Biskupa Sögur. Copenhagen: Hinn Íslenzka Bókmenntafèlag.

Müllenhoff, K., 1878. Althochdeutsche Sprachproben. Berlin: Weidmannsche Buchhandlung.

Mustanoja, T., 1960. A Middle English Syntax. Helsinki: Société Néophilologique.

Neumann, D., 1987. Objects and Spaces. A Study in the Syntax and Semantics of the German Case System. Tübingen: Narr. 
Neumann, D., 1996. "The dative and the grammar of body parts in German", in: The Grammar of Inalienability. A Typological Perspective on Body Part Terms and the PartWhole Relation, eds. H. Chappel and W. McGregor. Berlin/New York: De Gruyter, $745^{-779}$.

Nijdam, H., 2008. Lichaam, eer en recht in middeleeuws Friesland: een studie naar de Oudfriese boeteregisters, Dissertation. Hilversum: Uitgeverij Verloren.

Pedersen, H., 1907. "Neues und Nachträgliches.", in: Zeitschrift für vergleichende Sprachforschung 40, 129-217.

Polenz, P. von, 1969. "Der Pertinenzdativ und seine Satzbaupläne", in: Festschrift für Hugo Moser. Düsseldorf, 146-171.

Popkema, J., 2006. Grammatica Fries. Amsterdam: Unieboek Het Spectrum BV.

Rooryck, J., and E. Schoorlemmer, 2017. "Consanguinity and possession in varieties of Dutch", in: Journal of Germanic Linguistics 29 (1), 1-25.

Schmid, J., 2006. "Die freien Dative", in: Dependenz und Valenz: Ein internationales Handbuch der zeitgenössischen Forschung/Dependency and Valency: an International Handbook of Contemporary Research, eds. V. Ágel, L. M. Ludwig, H. W. Eroms, P. Hellwig, H. J. Heringer and H. Lobin. Berlin/New York: De Gruyter, 951-962.

Stiles, P. V., 2007. "The emergence of Old Frisian $s a^{*}$ “ "to seep, trickle”, in: Us Wurk ${ }_{56}^{6}$, $125^{-134}$

Szadrowsky, M., 1959. "Stil und Syntax der altfriesischen Rechtssprache (I)", in: Beiträge zur Geschichte der deutschen Sprache und Literatur 81, 131-160.

Szadrowsky, M., 1959. "Stil und Syntax der altfriesischen Rechtssprache (II)", in: Beiträge zur Geschichte der deutschen Sprache und Literatur 83, 80-131.

Vennemann, T., 2002. "On the Rise of 'Celtic' Syntax in Middle English.", in Middle English from tongue to text, eds. P. J. Lucas and A. M. Lucas. Bern: Peter Lang, 203-234. Van de Velde, F., and B. Lamiroy, 2017. "External Possessors in West Germanic and Romance: Differential Speed in the Drift toward NP Configurationality: (Inter) Subjectification and Directionality", in: Aspects of grammaticalization: (inter) subjectification, analogy and unidirectionality, eds. D. van Olmen, H. Cuykens and L. Ghesquiere. Berlin: Mouton de Gruyter, 353-399.

Van der Wal, M., 199o. "Passive constructions in Old Frisian", in: R. H. Bremmer Jr. et al. (eds.), Aspects of Old Frisian Philology, (ABäG 31-32), 495-505.

Wierzbicka, A., 1979. "Ethno-Syntax and the Philosophy of Language", in: Studies in Language 3 (3), 313-383. 